\title{
DITERMINAN EKSPORT KOMODITAS PROVINSI JAMBI
}

(Model Rantai Sebab Akibat dengan Pemakaian Intervening Eksport Produk Pertanian)

\author{
Adi Putra ${ }^{1}$ \\ Dosen Tetap Universitas Muhammadiyah Jambi ${ }^{1}$ \\ putramm@yahoo.co.id \\ Deka Veronica ${ }^{2}$ \\ Dosen Tetap Universitas Muhammadiyah Jambi² \\ dekaveronica28@,gmail.com
}

\begin{abstract}
Ringkasan
Transaksi perdagangan internasional bermanfaat untuk memperoleh cadangan devisa nasional maupun daerah. Ekspor adalah pembelian negara lain atas barang buatan perusahaan-perusahaan di dalam negeri, dimana ekspor secara langsung akan mempengaruhi pendapatan nasional, namun hubungan sebaliknya kenaikan pendapatan nasional belum tentu dapat menaikkan nilai eksport. Untuk itu perlu di diterminan pertumbuhan eksport produk pertanian Provinsi Jambi. Adapun metode yang dipergunakan dalam penelitian ini adalah metode deskriptif dengan data sekunder berupa data time series selanjutnya dilakukan analisis Analisis deskriptif Analisis Korelasi Analisis Regresi dan Analisis jalur (Path Analisis).

Adapun hasil yang didapatkan pada penelitian ini yaitu secara statistic Inflasi, Kurs dan pertumbuhan penduduk tidak terdapat pengaruh signifikan secara parsial terhadap Eksport Produk Pertanian dan terhadap eksport komoditas di Provinsi Jambi. Dari uji model diperoleh bahwa pada model rantai kausal pertama inflasi, kurs dan pertumbuhan penduduk berpengaruh langsung terhadap eksport produk pertanian. Sedangkan pada model rantai kausal kedua inflasi, pertumbuhan penduduk dan eksport produk pertanian berpengaruh langsung terhadap eksport komoditas Provinsi Jambi.selanjutnya dari hasil uji hipotesis pengaruh tidak langsung dengan variabel intervening eksport produk pertanian didapatkan inflasi, kurs dan pertumbuhan penduduk berpengaruh tidak langsung terhadap eksport komoditas Provinsi Jambi.
\end{abstract}

Kata kunci : Inflasi, Kurs dan pertumbuhan penduduk, eksport

\section{PENDAHULUAN}

Transaksi perdagangan internasional merupakan salah satu bentuk sumber pembiayaan yang sangat penting untuk meningkatkan, dimana dari transaksi perdagangan internasional tersebut akan diperoleh cadangan devisa baik skala nasional maupun daerah. sehingga dapat memacu kenaikan Gross Domestik Product sehingga mendorong peningkatan pertumbuhan ekonomi., dimana peningkatan cadangan devisa juga merupakan posisi bersih yang didapat dari transaksi ekspor dan impor dalam suatu negara.

(Anne Krueger dalam Nanga 2005) membedakan bentuk negara berdasarkan strategi pembangunan menjadi 2 golongan yaitu pertama negara yang strategi pembangunan berorientasi keluar (Outward-Oriented Countries) dan negara yang strategi pembangunan berorientasi kedalam (Inward-oriental countries), negara yang menerapkan strategi 
pembangunan yang berorientasi keluar memiliki kinerja pertumbuhan ekonomi yang jauh lebih baik dari pada negara-negara yang menerapkan strategi pembangunan yang berorientasi kedalam atau substitusi impor. Negara yang berorientasi keluar mempunyai perspektif dengan mendorong kebijakan makro ekonomi yang lebih baik, misalnya para pembuat kebijakan harus menjaga nilai tukar pada tingkat yang realistik, sehingga ekspor negara tersebut dapat bersaing dipasar luar negeri.

Ekspor merupakan pembelian negara lain atas barang buatan perusahaan-perusahaan di dalam negeri, dimana ekspor secara langsung akan mempengaruhi pendapatan nasional, namun hubungan sebaliknya kenaikan pendapatan nasional belum tentu dapat menaikkan nilai eksport. Ekspor merupakan salah satu variable injeksi dalam perekonomian suatu negara, artinya jika ekspor suatu negara meningkat maka perekonomian negara tersebut akan lebih meningkat lagi karena adanya proses multipler dalam perekonomian. Mankiw, (2006) mengemukakan ekspor merupakan kegiatan perdagangan internasional dari barang dan jasa yang diproduksi didalam negari dan dijual keluar negeri sehingga barang tersebut secara keseluruhan memberikan keuntungan yang lebih besar.

Sukirno, (2012) mengemukakan bahwa dalam analisis keseimbangan pendapatan nasional terutama dalam perekonomian terbuka, ekspor merupakan pengeluaran otonomi yang tidak ditentukan oleh pendapatan nasional, namun ekspor sangat ditentukkan oleh harga relative dari barang dalam negeri dipasaran luar negeri dan kemampuan barang dalam negeri untuk bersaing dipasaran dunia.

Pertumbuhan ekonomi dan prosesnya yang berkelanjutan merupakan kondisi utama bagi kelangsungan pembangunan ekonomi daerah. Karena jumlah penduduk terus bertambah dan berarti kebutuhan ekonomi juga bertambah, sehingga dibutuhkan penambahan pendapatan setiap tahun. Hal ini dapat diperoleh dengan peningkatan output agregat (barang dan jasa) atau Produk Domestik Regional Bruto (PDRB) setiap tahun menurut Tambunan (2001).

Berdasarkan uraian di atas, penelitian ini diberi judul "Pengaruh inflasi, kurs serta pertumbuhan penduduk terhadap eksport produk pertanian serta eksport komoditas Provinsi Jambi” sedangkan tujuan dari penelitian ini untuk menganalisis pengaruh inflasi, kurs serta pertumbuhan penduduk terhadap eksport produk pertanian serta total eksport komoditas Provinsi Jambi pada periode 2009-2018. 


\section{METODOLOGI}

\section{Metode Penelitian}

Metode yang dipergunakan dalam penelitian ini adalah metode deskriptif Sugiyono, (2014) menjelaskan penelitian desktiptif adalah penelitian yang dilakukan untuk mengetahui keberadaan variabel mandiri, baik satu variabel atau lebih variabel (variabel yang berdiri sendiri) tanpa membuat perbandingan atau mancari hubungan variabel satu sama lain yang diteliti dan dianalisis sehingga menghasilkan kesimpulan. Adapun data yang dipergunakan dalam penelitian ini adalah data sekunder berupa data time series yang bersifat komulatif berbentuk angka-angka yang didapatkan dari hasil penelitian, laporan instansi terkait, serta dari media elektronik.

\section{Teknik Analisis Data}

Analisis Statistik Deskriptif

Analisis deskriptif dilakukan untuk menganalisa data dengan cara menggambarkan data yang terkumpul sebagaimana adanya tanpa bermaksud membuat kesimpulan yang berlaku umum atau generalisasi. Analisis data dilakukan dengan statitistik Inferensial untuk mendeskripsikan data dan membuat kesimpulan.

\section{Analisis Korelasi}

Analisis korelasi digunakan untuk mengetahui keeratan hubungan antara dua variabel serta untuk mengetahui arah hubungan yang terjadi. Koefisien korelasi sederhana menunjukkan seberapa besar hubungan yang terjadi antara dua variabel sebagai berikut: (Sugiyono 2007)

$$
\begin{aligned}
0,00-0,199 & =\text { sangat rendah } \\
0,20-0,399 & =\text { rendah } \\
0,40-0,599 & =\text { sedang } \\
0,60-0,799 & =\text { kuat } \\
0,80-1,000 & =\text { sangat } \text { kuat }
\end{aligned}
$$

\section{Analisis Regresi}

Analisis regresi dilakukan untuk melihat pengaruh antara satu atau lebih variabel bebas (X) dengan satu peubah tak bebas (Y). pengujian ini dilakukan untuk mendapatkan pengaruh antar variabel penelitian secara parsial sehingga didapatkan model rantai kausal pengaruh antar variabel independenya dengan variabel dependent.

\section{Analisis Jalur}

Analisis jalur (Path Analisis) dig8unakan untuk memudahkan pengujian hipotesis dari hubungan antar variabel yang cukup rumit. Path Analisis pada penelitian dengan model rekursif dengan arah semua anak panah menuju ke satu arah dan dipergunakan untuk 
menganalisis hubungan akibat antar satu variabel dengan variabel lainnya berupa pengaruh langsung dan tidak langsung (direct and direct effect).

Struktur hubungan kausalitas Diagram Jalur (Path Diagram) dari beberapa variabel yang diteliti berupa variabel Independent inflasi (X1), Kurs (X2) dan Pertumbuhan penduduk (X3), dengan variabel Intervening (Z) pertumbuhan ekspor komoditas pertanian dan variabel Dependent (Y) pertumbuhan ekspor komoditas Provinsi Jambi:

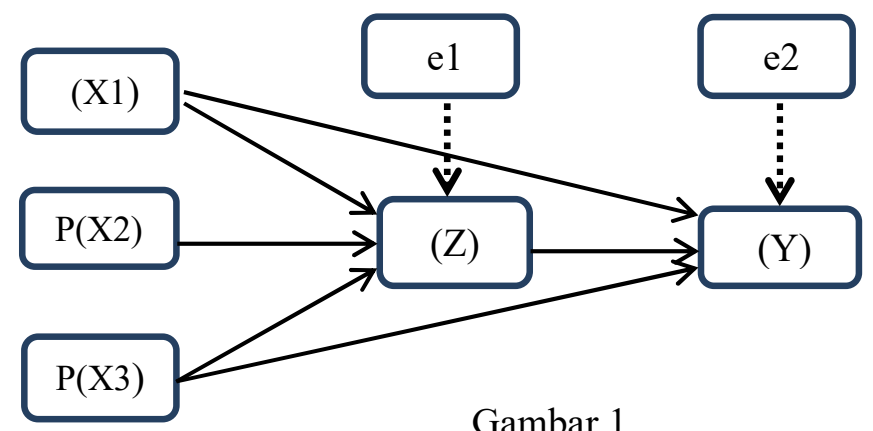

Diagram Jalur (Path Diagram)

Adapun koefisien jalur dari persamaan struktural dalam penelitian ini dimana Persamaan Jalur Sub Struktural pertama

Persamaan Jalur Sub Struktural kedua

$$
Z=\rho z X_{1}+\rho z X_{2}+\rho z X_{3}+\varepsilon_{1}
$$

$$
Y=\rho y X_{1}+\rho y X_{3}+\rho y Z+\varepsilon_{2}
$$

Pengaruh langsung (Direct Effect) Hasil dari X1 dan X2 dan $\mathrm{X}_{3}$ terhadap Z, dan hasil Z terhadap Y, lebih sederhana dapat dilihat dari persamaan berikut :

$$
\begin{array}{ll}
\mathrm{X}_{1}, \mathrm{X}_{2}, \mathrm{X}_{3} & \rightarrow \mathrm{Z}: \rho z X_{1}, \rho z X_{2}, \rho z X_{3} \\
\mathrm{X}_{1}, \mathrm{X}_{3}, \mathrm{Z}_{3} & \rightarrow \mathrm{Z}: \rho y X_{1}, \rho y X_{3}, \rho y Z_{1} \\
\mathrm{Z} & \rightarrow \mathrm{Y}: \rho y Z, \varepsilon 1 \\
\mathrm{Y} & \rightarrow \varepsilon 2
\end{array}
$$

Hasil tidak langsung (indirect effect) adalah dari $\mathrm{X}$ terhadap $\mathrm{Z}$ melalui $\mathrm{Y}$, atau lebih sederhana dapat dilihat sebagi berikut :

$\mathrm{X} \rightarrow \mathrm{Z} \quad \rightarrow \quad \mathrm{Y}:(\rho \mathrm{zx}),(\rho \mathrm{z})$

Rumus diatas memperlihatkan bahwa hasil langsung diperoleh dari hasil analisis jalur nilai beta, sedangkan hasil tidak langsung diperoleh dengan mengalikan koefisien rho (nilai beta) yang melewati variabel antara (penghubung) dengan variabel langsungnya.

\section{Pengujian Hipotesis}

Pengujian hipotesis diperlukan untuk menguji tingkat signifikan pengaruh variabel independen terhadap variabel dependen. Pegujian hipotesis dilakukan dengan membandingkan nilai t-Sig dengan $\alpha$. Hipotesis dijelaskan sebagai berikut :

1. $\mathrm{H}_{0}: \rho \mathrm{zX}=0, \quad$ Artinya tidak terdapat pengaruh variabel $\mathrm{X}$ secara parsial terhadap $\mathrm{Z}$ 
$\mathrm{H}_{1}: \rho \mathrm{zX} \neq 0, \quad$ Artinya terdapat pengaruh variabel $\mathrm{X}$ secara parsial terhadap $\mathrm{Z}$

2. $\mathrm{H}_{0}: \rho y X=0$, Artinya tidak terdapat pengaruh variabel $\mathrm{X}$ secara parsial terhadap $\mathrm{Y}$

$\mathrm{H}_{2}: \rho y \mathrm{X} \neq 0$, Artinya terdapat pengaruh variabel $\mathrm{X}$ secara parsial terhadap $\mathrm{Y}$

3. $\mathrm{H}_{0}: \rho \mathrm{ZX}_{1} \rho \mathrm{ZX}_{2} \rho \mathrm{ZX}_{3}=0$, Artinya tidak terdapat pengaruh variabel $\mathrm{X}$ secara simultan terhadap Z

$\mathrm{H}_{3}: \rho \mathrm{zx}_{1} \rho \mathrm{ZX}_{2} \rho \mathrm{zx}_{3} \neq 0, \quad$ Artinya terdapat pengaruh variabel $\mathrm{X}$ secara simultan terhadap $\mathrm{Z}$

4. $\mathrm{H}_{0}: \rho \mathrm{yx}_{1} \rho \mathrm{yx}_{3} \rho \mathrm{z}=0$, Artinya tidak terdapat pengaruh variabel $\mathrm{X}$ secara simultan terhadap Y

$\mathrm{H}_{4}: \rho \mathrm{x}_{1} \rho \mathrm{x}_{3} \rho \mathrm{z} \neq 0, \quad$ Artinya terdapat pengaruh variabel $\mathrm{X}$ secara simultan terhadap $\mathrm{Y}$ 5. $\mathrm{H}_{0}: \rho x z y=0, \quad$ Artinya tidak terdapat pengaruh variabel $\mathrm{X}$ secara simultan terhadap $\mathrm{Y}$

$\mathrm{H}_{5}: \rho x z y \neq 0, \quad$ Artinya terdapat pengaruh variabel $\mathrm{X}$ secara simultan terhadap $\mathrm{Y}$

Pasangan Hipotesis tersebut kemudian diuji untuk diketahui tentang diterima atau ditolaknya hipotesis. Selanjutnya dilakukan uji signifikan koefisien berganda, dengan tarap signifikan 5\% dengan rumus sebagai berikut :

$$
\text { Fhitung }=\frac{(n-k-1) R^{2}}{k\left(1-R^{2}\right)}
$$

dimana, $R^{2}$ merupakan koefisien korelasi ganda, $k$ adalah banyaknya variabel independen dan $\mathrm{n}$ adalah jumlah anggota sample. Dengan distribusi F dengan pembilang (k) dan dk penyebut (nk-1) dengan ketentuan sebagai berikut : Jika $\mathrm{t}$ hitung $\leq \mathrm{t}$ tabel, H0 diterima, Jika $\mathrm{t}$ hitung $\geq \mathrm{t}$ tabel, H0 ditolak

\section{Operasional Variabel Penelitian}

Operasionalisasi variabel penelitian dapat dijelaskan sebagai berikut:

1. Ekspor komoditas Provinsi Jambi adalah proses transportasi semua barang atau komoditas dari Provinsi Jambi ke Luar Negeri yang diukur berupa perkembangan total eksport selama periode 2009-2018 dalam satuan persen.

2. Ekspor komoditas pertanian adalah proses transportasi komoditas pertanian dari Provinsi Jambi ke Luar Negeri yang diukur dari perkembangan total eksport selama periode 20092018 dalam satuan persen.

3. Inflasi yaitu suatu proses dari suatu peristiwa kenaikan harga yang berlangsung secara terus-menerus dan saling mempengaruhi yang diukur dari perkembangan inflasi selama periode 2009-2018 dalam satuan persen.

4. Kurs yaitu nilai nilai tukar Rupiah terhadap Dollar Amerika yang dipergunakan dalam perdagangan internasional yang diukur dari perkembangan Kurs selama periode 20092018 dalam satuan persen. 
5. Pertumbuhan penduduk yaitu perubahan jumlah individu dalam sebuah populasi penduduk di Provinsi Jambi yang diukur dari perkembangan penduduk selama periode 2009-2018 dalam satuan persen.

\section{HASIL PENELITIAN}

\section{Hasil Analisis Deskriptif}

Setelah dilakukan analisis maka dapat di deskripsikan suatu gejala, peristiwa, kejadian yang terjadi. Seperti pada tabel 1 berikut:

Tabel 1.

Hasil Analisis Perkembangan Antar Variabel yang Di Uji periode 2010-2018

\begin{tabular}{|c|c|r|c|c|c|}
\hline Tahun & $\begin{array}{c}\text { Eksport komoditas Provinsi } \\
\text { Jambi }(\%)\end{array}$ & $\begin{array}{c}\text { Eksport Pertanian } \\
(\mathrm{Kg})\end{array}$ & $\begin{array}{c}\text { Inflasi } \\
(\mathbf{\%})\end{array}$ & $\begin{array}{c}\text { Kurs } \\
(\%)\end{array}$ & $\begin{array}{c}\text { Pertumbuhan } \\
\text { penduduk }(\%)\end{array}$ \\
\hline 2010 & 62,93 & 27,28 & 1,9 & $(20,68)$ & 9,66 \\
\hline 2011 & 184,90 & $(16,54)$ & $(0,12)$ & 6,3 & 1,93 \\
\hline 2012 & $(8,78)$ & $(14,34)$ & 0,25 & 7,36 & 1,88 \\
\hline 2013 & $(11,87)$ & 16,18 & 6,36 & 12,51 & 1,78 \\
\hline 2014 & $(6,06)$ & 36,06 & $(0,21)$ & 13,17 & 1,72 \\
\hline 2015 & 1,70 & $(21,12)$ & 0,6 & $(0,89)$ & 1,67 \\
\hline 2016 & $(9,10)$ & 101,84 & 1,5 & 0,46 & 1,62 \\
\hline 2017 & 20,82 & 6,34 & 0,63 & 6,55 & 1,57 \\
\hline 2018 & 20,73 & & & \\
\hline
\end{tabular}

Sumber: SEKI BI, diolah Kementerian Perdagangan data diolah 2019

Hasil diatas menjelaskan bahwa periode tersebut semua variabel yang di uji perkembangannya sangat berfluktuatif, dimana perkembangan eksport komoditas Provinsi Jambi tertinggi pada tahun 2011 sebesar 184,9\%, dan terendah 2013 sebesar $-11,87$. Perkembangan eksport pertanian tertinggi tahun 2017 sebesar 101,84\% yang terendah 2016 sebesar -21,12\%. Perkembangan Inflasi tertinggi pada tahun 2014 sebesar 6,36\% terendah 2015 sebesar $-0,21 \%$, perkembangan kurs tertinggi pada tahun 2015 sebesar $13,17 \%$ terendah 2010 sebesar $-20,68 \%$, serta perkembangan pertumbuhan penduduk tertinggi pada tahun 2011 sebesar $1,93 \%$ yang terendah 2018 sebesar $-1,57 \%$

\section{Hasil Analisis Korelasi}

Analisis korelasi untuk mengukur kekuatan asosiasi (hubungan) linier antara variabel, serta menyatakan derajat keeratan hubungan antar variabel terkait.

1. Koefisien korelasi inflasi, kurs, pertumbuhan penduduk dan eksport komoditas pertanian Provinsi Jambi terhadap eksport produk pertanian secara parsial masing-masing sebesar $(0,188),(-0,198),(0,106),(-0,115)$. Hasil tersebut menggambarkan derajat kekuatan hubungan yang sangat rendah pada rentang klasifikasi 0,00-0,199.

Tabel 2 


\begin{tabular}{|c|c|c|c|c|c|c|}
\hline & & $\begin{array}{c}\text { Eksport } \\
\text { Komoditas }\end{array}$ & $\begin{array}{c}\text { Eksport Produk } \\
\text { Pertanian }\end{array}$ & Inflasi & Kurs & $\begin{array}{l}\text { Pertumbuhan } \\
\text { Penduduk }\end{array}$ \\
\hline $\begin{array}{l}\text { Eksport } \\
\text { Komoditas }\end{array}$ & $\begin{array}{l}\text { Pearson Correlation } \\
\text { Sig. (2-tailed) } \\
\mathrm{N}\end{array}$ & $\begin{array}{l}1 \\
9\end{array}$ & $\begin{array}{c}-.115 \\
.768 \\
9\end{array}$ & $\begin{array}{c}-.237 \\
.539 \\
9\end{array}$ & $\begin{array}{c}-.242 \\
.531 \\
9\end{array}$ & $\begin{array}{c}.223 \\
.564 \\
9\end{array}$ \\
\hline $\begin{array}{l}\text { Eksport Produk } \\
\text { Pertanian }\end{array}$ & $\begin{array}{l}\text { Pearson Correlation } \\
\text { Sig. (2-tailed) } \\
\mathrm{N}\end{array}$ & $\begin{array}{c}-.115 \\
.768 \\
9 \\
\end{array}$ & $\begin{array}{l}1 \\
9 \\
9\end{array}$ & $\begin{array}{c}.188 \\
.628 \\
9 \\
\end{array}$ & $\begin{array}{c}-.198 \\
.610 \\
9 \\
\end{array}$ & $\begin{array}{c}.106 \\
.787 \\
9 \\
\end{array}$ \\
\hline Inflasi & $\begin{array}{l}\text { Pearson Correlation } \\
\text { Sig. (2-tailed) } \\
\mathrm{N}\end{array}$ & $\begin{array}{c}-.237 \\
.539 \\
9\end{array}$ & $\begin{array}{c}.188 \\
.628 \\
9 \\
\end{array}$ & $\begin{array}{l}1 \\
9\end{array}$ & $\begin{array}{c}.022 \\
.954 \\
9\end{array}$ & $\begin{array}{c}.111 \\
.777 \\
9\end{array}$ \\
\hline Kurs & $\begin{array}{l}\text { Pearson Correlation } \\
\text { Sig. (2-tailed) } \\
\mathrm{N}\end{array}$ & $\begin{array}{c}-.242 \\
.531 \\
9\end{array}$ & $\begin{array}{c}-.198 \\
.610 \\
9\end{array}$ & $\begin{array}{c}.022 \\
.954 \\
9\end{array}$ & $\begin{array}{l}1 \\
9\end{array}$ & $\begin{array}{l}-.871^{* *} \\
.002 \\
9\end{array}$ \\
\hline $\begin{array}{l}\text { Pertumbuhan } \\
\text { Penduduk }\end{array}$ & $\begin{array}{l}\text { Pearson Correlation } \\
\text { Sig. (2-tailed) } \\
\mathrm{N}\end{array}$ & $\begin{array}{c}.223 \\
.564 \\
9\end{array}$ & $\begin{array}{c}.106 \\
.787 \\
9\end{array}$ & $\begin{array}{c}.111 \\
.777 \\
9\end{array}$ & $\begin{array}{c}-.871^{* *} \\
.002 \\
9\end{array}$ & $\begin{array}{l}1 \\
9\end{array}$ \\
\hline
\end{tabular}

**. Correlation is significant at the 0.01 level (2-tailed).

2. Koefisien korelasi inflasi, kurs, pertumbuhan penduduk dan eksport komoditas pertanian Provinsi Jambi terhadap eksport produk pertanian secara parsial masing-masing sebesar $(0,188),(-0,198),(0,106),(-0,115)$. Hasil tersebut menggambarkan derajat kekuatan hubungan yang sangat rendah pada rentang klasifikasi 0,00-0,199.

3. Koefisien korelasi inflasi, kurs, dan pertumbuhan penduduk terhadap eksport komoditas Provinsi Jambi secara parsial masing-masing sebesar $(-0,237),(-0,242), \quad(0,223)$ menunjukan bahwa derajat kekuatan hubungan pada kriteria rendah pada rentang klasifikasi $0,20-0,399$.

4. Koefisien korelasi inflasi terhadap kurs dan pertumbuhan penduduk secara parsial sebesar $(0,022)$ dan $(0,111)$, menunjukan derajat kekuatan hubungan pada kriteria sangat rendah pada rentang klasifikasi $0,00-0,199$.

5. Koefisien korelasi antara kurs dengan pertumbuhan penduduk secara parsial sebesar (0,871) dengan arah negative menunjukan derajat kekuatan hubungan yang sangat kuat pada rentang klasifikasi $0,80-1,000$.

Hasil pengujian secara simultan diketahui bahwa hubungan antara inflasi, kurs, pertumbuhan penduduk terhadap eksport produk pertanian (model 1) dan terhadap eksport komoditas di Provinsi Jambi (model 2) didapatkan nilai masing-masing sebesar 0,337 dan 0,358. Hasil tersebut menjelaskan bahwa derajat hubungan antar variabel termasuk pada kriteria 0,20-0,399 dengan tingkat derajat kekuatan hubungan termasuk pada klasifikasi 
rendah/lemah. Koefisien korelasi variabel-variabel independen terhadap variabel dependent secara simultan terlihat pada tabel 3 sebagai berikut.

Tabel 3.

Korelasi Secara Simultan Variabel Independen Terhadap Variabel Dependent

\begin{tabular}{|c|r|r|r|r|}
\hline Model & $\mathrm{R}$ & \multicolumn{1}{|c|}{ R Square } & Adjusted R Square & \multicolumn{1}{c|}{ Std. Error of the Estimate } \\
\hline 1 & $.337^{\mathrm{a}}$ & .114 & -.418 & 46.03962 \\
\hline 2 & $.358^{\mathrm{a}}$ & .128 & -.395 & 74.84021 \\
\hline
\end{tabular}

Sumber: Hasil olahan Data dengan spps 23

Hasil analisis SPSS pada tabel 3 juga mememperlihatkan bahwa nilai koefisien determinasi (R-Square) pada model 1 didapatkan sebesar 0,114, dimana nilai tersebut menjelaskan besarnya pengaruh antara inflasi, kurs dan pertumbuhan penduduk terhadap eksport produk pertanian sebesar 11,4\%, sedangkan 88,6\% dipengaruh variabel lain $\left(\mathrm{e}_{1}\right)$. Sedangkan koefisien Determinasi pada model 2 besarnya pengaruh inflasi, Kurs dan pertumbuhan penduduk terhadap eksport komoditas produk pertanian Provinsi Jambi secara simultan sebesar 0,128, dimana nilai tersebut menunjukan besarnya pengaruh antara variabel independen terhadap dependent secara simultan adalah $12,8 \%$ dan $87,2 \%$ besarnya pengaruh variabel lain $\left(\mathrm{e}_{2}\right)$.

\section{Hasil Analisis Regresi}

Hasil Analisis regresi untuk pengujian model rantai kausal Dependent Variable eksport produk pertanian dengan Predictors pertumbuhan penduduk, Inflasi, kurs didapatkan Sig 0,883 $(0,883>0,05)$ artinya secara statistic $\mathrm{H}_{\mathrm{o}}$ diterima dan $\mathrm{H}_{\mathrm{i}}$ ditolak dan model rantai kausal tersebut tidak linear. Selanjutnya pada pengujian model rantai kausal eksport komoditas Provinsi Jambi dengan eksport produk pertanian, pertumbuhan penduduk, Inflasi sebagai Predictors didapatkan Sig 0,862 (0,862>0,05 maka $\mathrm{H}_{\mathrm{o}}$ diterima dan $\mathrm{H}_{\mathrm{i}}$ ditolak dan model rantai kausal tersebut juga kriteria tidak linear.

Dari analisis regresi didapatkan nilai Standardized Coefficients (model 1) variabel Inflasi $(0,246)$, Kurs $(-0.560)$ dan pertumbuhan penduduk $(-0,410)$, dimana nilai tersebut lebih besar dari $\alpha(0,05)$ sehingga secara statistik disimpulkan tidak terdapat pengaruh signifikan secara parsial antara variabel kausal terhadap Y (Eksport Produk Pertanian). Sedangkan pada (model 2) didapatkan nilai Standardized Coefficients inflasi $(-0,248)$, pertumbuhan penduduk (0.261) dan eksport produk pertanian $(-0,096)$ yang juga lebih besar dai $\alpha(0,05)$, sehingga hasil tersebut juga menjelaskan tidak ada pengaruh yang significan anatara variabel $\mathrm{X}$ terhadap variabel Y (Eksport Komoditas Provinsi Jambi) secara parsial. 


\section{Hasil Analisi Jalur}

Besarnya sumbangan (kontribusi) koefisien jalur pada setiap diagram jalur dari hubungan kausal antar variabel $\mathrm{X}_{1} \mathrm{X}_{2}$ dan $\mathrm{X}_{3}$ terhadap $\mathrm{Y}$ serta dampaknya terhadap $\mathrm{Z}$. didapatkan hasil berupa analisis jalur sebagai berikut:

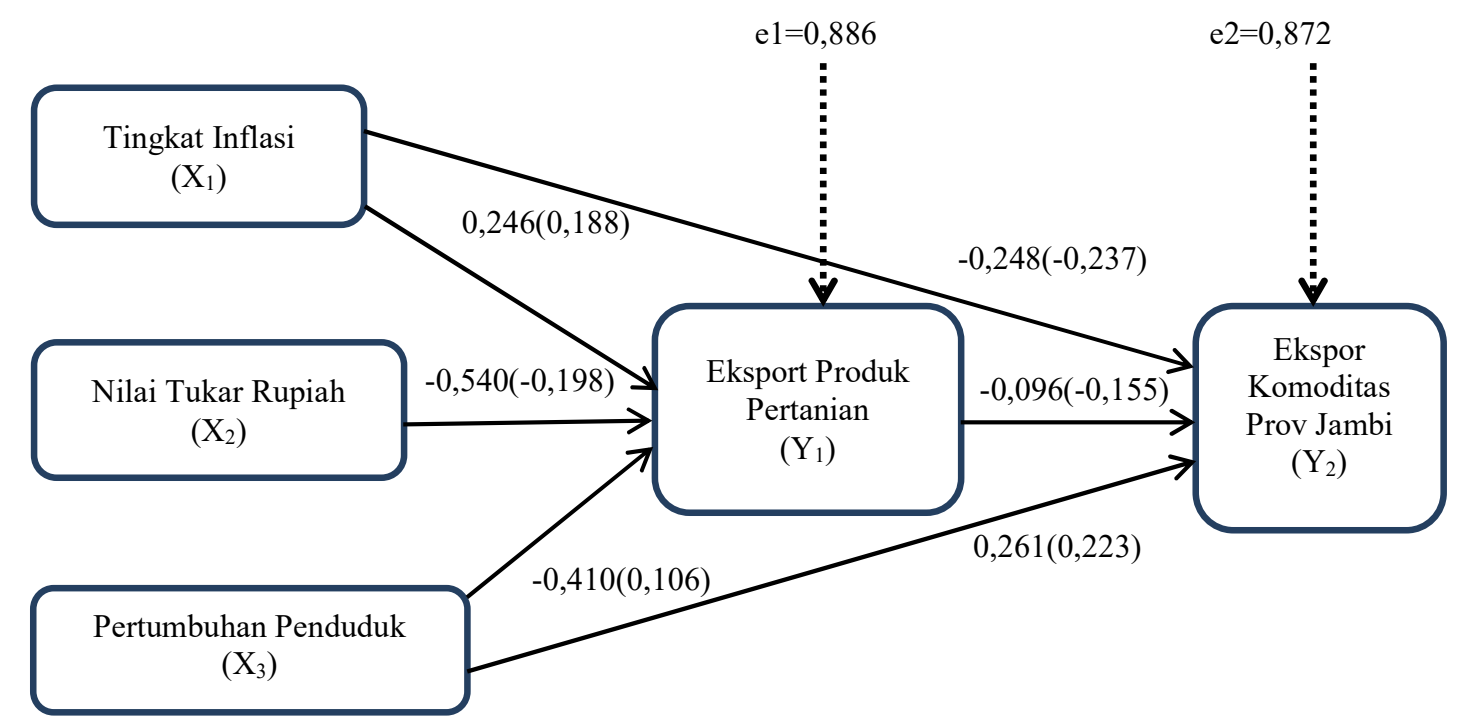

Gambar 2.

Hasil Analisis Jalur

Dimana pada Model rantai kausal pertama memperlihatkan :

Inflasi berpengaruh langsung terhadap eksport produk pertanian sebesar 0,246, sedangkan hubungannya sebesar 0,188, kurs memberikan pengaruh langsung pada eksport produk pertanian sebesar -0,540, sedangkan hubungannya sebesar -0,198. Sedangkan pertumbuhan penduduk memberikan pengaruh langsung pada $\mathrm{Y}_{1}$ (eksport produk pertanian) sebesar -0,410, sedangkan hubungannya adalah 0,106 .

\section{Model rantai kausal kedua:}

Inflasi memberikan pengaruh negative secara langsung terhadap eksport komoditas Provinsi Jambi sebesar -0,248, sedangkan hubungannya sebesar -0,237, pertumbuhan penduduk memberikan pengaruh positif secara langsung terhadap eksport komoditas Provinsi Jambi sebesar 0,261 sedangkan hubungannya sebesar 0,233. Sedangkan eksport produk pertanian memberikan pengaruh negative secara langsung pada eksport komoditas Provinsi Jambi sebesar -0,096, sedangkan hubungannya $-0,155$. 


\section{Pengaruh tidak langsung:}

Inflasi memberikan pengaruh negative tidak langsung pada eksport komoditas Provinsi Jambi melalui eksport produk pertanian sebesar 0,246 x -0,096 =-0,023, sedangkan kurs memberikan pengaruh tidak langsung secara positif terhadap eksport komoditas Provinsi Jambi melalui eksport produk pertanian sebesar $-0,540 \times-0,096=0,051$. Selanjutnya pertumbuhan penduduk juga memberikan pengaruh tidak langsung secara positif terhadap eksport komoditas Provinsi Jambi melalui eksport produk pertanian sebesar $-0,410 \times-0,096=0,039$.

\section{Pembahasan}

Hasil analisis menunjukan bahwa pada periode 2010-2018 perkembangan Inflasi, kurs dan pertumbuhan penduduk sangat berfluktuatif, ketidakstabilan variabel-variabel tersebut mempengaruhi nilai eksport produk pertanian dan nilai eksport komoditas di provinsi Jambi baik secara langsung maupun secara tidak langsung. Sedangkan dari analisis pengaruh tidak langsung dengan penggunaan variabel intervening didapatkan hasil variabel Inflasi berpengaruh negative tidak langsung terhadap eksport komoditas Provinsi Jambi melalui eksport produk pertanian, sedangkan kurs memberikan pengaruh tidak langsung secara positif terhadap eksport komoditas Provinsi Jambi melalui eksport produk pertanian. Variabel pertumbuhan penduduk juga memberikan pengaruh tidak langsung secara positif terhadap eksport komoditas Provinsi Jambi melalui eksport produk pertanian.

Hasil tersebut sesuai dengan pernyataan Sulasmiyati, (2016) dimana kurs dapat berpengaruh positif dan negatif terhadap ekspor, pengaruh positif terjadi ketika penguatan nilai tukar dapat mempengaruhi ekspor sehingga ekspor dapat bertambah. Kurs dapat mempengaruhi harga suatu barang yang diekspor, sehingga ketika nilai tukar rupiah terhadap dollar menguat, maka harga barang ekspor akan naik. Inflasi juga dapat memberikan pengaruh yang negatif ataupun positif terhadap ekspor, pengaruh negatif dari inflasi yaitu ketika terjadi inflasi, maka harga komoditi akan meningkat, dimana peningkatan harga komoditi disebabkan produksi untuk menghasilkan komoditi menghabiskan banyak biaya, harga komoditi yang mahal juga akan membuat komoditi tersebut tidak bersaing di pasar global.

Persoalan pertumbuhan penduduk juga sangat berkaitan dengan aspek perencanaan pada pembangunan, pertumbuhan penduduk yang besar bisa sebagai aset sekaligus sebagai beban dalam pembangunan. Sebagai aset apabila Pertumbuhan penduduk diiringi juga dengan peningkatan kualitas maupun keahliannya sehingga mampu mendorong peningkatan produksi di daerah dan perekonomian nasional sehingga pada gilirannya akan mampun meningkatkan 
pendapatannya. Pertumbuhan penduduk yang tinggi akan mengurangi output per kapita dan akan semakin parah jika pertumbuhan penduduk tanpa adanya kenaikan input yang significan pada aspek capital, sehingga hukum (deminishing return) terjadi, dimana tambahan hasil yang semakin menurun dan akan mengurangi pertumbuhan output.

Pertumbuhan penduduk yang tinggi juga akan menyebabkan kebutuhan konsumsi lebih banyak dari pada kebutuhan untuk investasi, sehingga sumberdaya yang ada hanya dialokasikan untuk meningkatkan kapital setiap tenaga kerja, sehingga pola pikiran para ekonom klasik terjadi, dimana Adam Smith dengan teori spesialisasi (specialization and division of labor) mengajukan hipotesis bahwa pertumbuhan penduduk yang tinggi akan dapat menaikkan output melalui ekspansi pasar baik pasar dalam negeri maupun luar negeri. Pertumbuhan penduduk yang tinggi juga akan mendorong perubahan teknologi dan pertumbuhan ekonomi melalui mobilitas dan adaptasi mereka sehingga akan mendorong penggunaan teknologi baru, pengelolaan sumberdaya alam yang lebih efisien, dan akhirnya mendorong eksport dan pertumbuhan ekonomi daerah.

\section{KESIMPULAN}

Adapun kesimpulan yang dapat ditarik dari penelitian ini adalah sebagai berikut :

1. Dari analisis regresi didapatkan nilai Standardized Coefficients Inflasi, Kurs dan pertumbuhan penduduk lebih besar dari $\alpha(0,05)$ sehingga secara statistik dijelaskan tidak terdapat pengaruh signifikan secara parsial antara variabel kausal terhadap Y (Eksport Produk Pertanian). Selanjutnya pada pengujian berikutnya didapatkan nilai Standardized Coefficients inflasi, pertumbuhan penduduk dan eksport produk pertanian yang juga lebih besar dari $\alpha(0,05)$, sehingga secara statistic juga dijelaskan bahwa tidak terdapat pengaruh significan anatara variabel $\mathrm{X}$ terhadap variabel Y (Eksport Komoditas Provinsi Jambi) secara parsial.

2. Hasil uji model diperoleh bahwa pada model rantai kausal pertama dinyatakan bahwa inflasi, kurs dan pertumbuhan penduduk berpengaruh langsung terhadap eksport produk pertanian. Sedangkan pada model rantai kausal kedua juga didapati inflasi, pertumbuhan penduduk dan eksport produk pertanian berpengaruh langsung terhadap eksport komoditas Provinsi Jambi.

3. Dari hasil uji hipotesis pengaruh tidak langsung dengan variabel intervening eksport produk pertanian didapatkan inflasi, kurs dan pertumbuhan penduduk berpengaruh tidak langsung terhadap eksport komoditas Provinsi Jambi. 


\section{DAFTAR PUSTAKA}

Anindita, Ratya dan Michael R. Reed. 2008. Bisnis dan Perdagangan Internasional. Yogyakarta : Andi.

Badan Pusat Statistik, 2019. Statistik Indonesia Tahun 2018.: Badan Pusat Statistik https://www.bps.go.id/subject/8/ekspor-impor.html\#subjekViewTab3

Badan Pusat Statistik, 2019. Statistik Indonesia Tahun 2018.: Badan Pusat Statistik Statistik Perdagangan Luar Negeri Provinsi Jambi 2018.

Engkos Achmad Kuncoro dan Riduan, 2007Cara Menggunakandan Memakai Analisis Jalur (Path Analysis), penerbit: Alfabeta, Bandung.

Ghozali, Imam. 2011. Aplikasi Analisis Multivariate dengan Program IBM SPSS19. Semarang: Badan Penerbit Universitas Diponegoro.

Mahendra, I Gede Yoga dan I Wayan Wita Kesumajaya. 2015. Analisis Pengaruh Investasi, Inflasi, Kurs Dollar Amerika Serikat, dan Suku Bunga Kredit terhadap Ekspor Indonesia Tahun 1992-2012. E-Jurnal Ekonomi Pembangunan Universitas Udayana.

Mankiw N,Gregory. 2006. Makro Ekonomi, Terjemahan: Fitria Liza, Imam. Nurmawan, Jakarta: Penerbit Erlangga

Nanga, Muana. 2005. Makro Ekonomi: Teori, Masalah, dan Kebijakan, Jakarta: PT Grafindo Persada.

Sugiyono, (2014) Metode Penelitian Kuantitatif dan Kualitatif. Bandung : Alfabeta.

Sukirno, Sadono. 2012. Makroekonomi Teori Pengantar Edisi Ketiga. Jakarta: Rajawali. Pers

RAy Fani Arning Putri Suhadak Sri Sulasmiyati (2016) Pengaruh Inflasi dan Nilai Tukar Terhadap Ekspor Indonesia Komoditi Tekstil Dan Elektronika Ke Korea Selatan (Studi Sebelum Dan Setelah Asean Korea Free Trade Agreement Tahun 2011) Fakultas Ilmu Administrasi Universitas Brawijaya Malang Jurnal Administrasi Bisnis (JAB)|Vol. 35 No. 1 Juni 2016 administrasibisnis.studentjournal.ub.ac.id 127

Tambunan, Tulus. 2001. Perekonomian Indonesia: Teori Dan Temuan Empiris. Cetakan Kedua. Jakarta. 